\title{
Eksplorasi Nilai Kepahlawanan Kyai Hasan Mukmin Daerah Sidoarjo sebagai Bahan Pendidikan Karakter
}

\author{
Amelia Widya Hanindita ${ }^{1}$ \\ Universitas PGRI Adi Buana Surabaya \\ ameliahanindita@unipasby.ac.id ${ }^{1}$
}

DOI: https://doi.org/10.32528/bb.v6i2.5786

First received: 28-08-2021 Final proof received: 30-09-2021

\begin{abstract}
ABSTRAK
Pahlawan merupakan sosok teladan, rela berkorban, berani, dan berjasa bagi suatu bangsa. Dengan demikian, generasi muda harus dapat memetik pelajaran dari kisah perjuangan para pahlawan dan menerapkan nilai kepahlawanan tersebut. Hal ini dilakukan untuk menguatkan pendidikan karakter agar generasi muda lebih kokoh dalam menghadapi tantangan di abad ke-21. Dalam penelitian ini akan dibahas nilai kepahlawanan yang ada dalam diri Kyai Hasan Mukmin dan pemanfaatan nilai kepahlawanannya sebagai bahan ajar pendidikan karakter. Penelitian ini dilakukan karena kisah perjuangan Kyai Hasan Mukmin menarik untuk ditelusuri lebih mendalam dan terdapat nilai kepahlawanan dalam sosoknya. Tujuan penelitian ini adalah untuk mendeskripsikan nilai kepahlawanan dalam diri Kyai Hasan Mukmin dan pemanfaatan nilai kepahlawanan tersebut sebagai bahan ajar pendidikan karakter. Pendekatan yang digunakan kualitatif deskriptif. Hasil penelitian menunjukkan bahwa nilai kepahlawanan yang ditemukan dalam diri Kyai Hasan Mukmin adalah ulet, rela berkorban, berjiwa pemimpin, teladan, gigih, pantang mundur, dan berjiwa pelopor. Kemudian, pemanfaatan nilai kepahlawanan sebagai bahan ajar pendidikan karakter dideskripsikan melalui cerita narasi dengan judul "Kyai Hasan Mukmin, Pahlawan dari Sidoarjo". Hasil penelitian dapat diimplementasikan untuk menguatkan pendidikan karakter bagi mahasiswa.

Kata kunci: Kyai Hasan Mukmin; nilai kepahlawanan; pendidikan karakter
\end{abstract}

\begin{abstract}
Heroes are model figure, willing to sacrifice, brave, and meritorious for a nation. Therefore, the young generations must be able to take lessons from the stories of the heroes struggles and apply these heroic values. This matter is done to strengthen character education so that the younger generation is stronger in facing challenges in the 21st century. In this study, we will discuss the heroic values that exist in Kyai Hasan Mukmin and the use of heroic values as teaching materials for character education. This research was conducted because the story of Kyai Hasan Mukmin's struggle is interesting to dig deeper and there is a heroic value in his figure.
\end{abstract}


The purpose of this study is to describe the value of heroism in Kyai Hasan Mukmin and the use of these heroic values as teaching materials for character education. The approach used is descriptive qualitative. The results of the study indicate that the heroic values found in Kyai Hasan Mukmin are tenacious, willing to sacrifice, spirited leader, exemplary, persistent, unyielding, and pioneering spirit. Then, the use of heroic values as teaching materials for character education is described through a narrative story with the title "Kyai Hasan Mukmin, Hero from Sidoarjo". The results of the research can be implemented to strengthen character education for college student.

\section{Keywords: Kyai Hasan Mukmin; heroic value; character education}

\section{PENDAHULUAN}

Pahlawan merupakan sosok teladan, rela berkorban, berani, dan berjasa bagi individu, kelompok, suku, bangsa, dan negara. Indonesia dapat merasakan kemerdekaan berkat adanya para pahlawan tangguh yang rela mengorbankan nyawanya untuk berperang mengusir penjajah. Para pahlawan sangat berani berjuang bagi bangsa Indonesia. Oleh karena itu, untuk menghormati jasanya, para pahlawan yang gugur dikebumikan di taman makam pahlawan. Selain itu, ada lagu nasional yang didedikasikan untuk para pahlawan. Salah satu lagu tersebut berjudul gugur bunga. Tidak hanya itu, agar seluruh generasi bangsa selalu mengingat jasa para pahlawan pada tanggal 10 November dijadikan sebagai peringatan Hari Pahlawan.

Generasi penerus bangsa harus dapat memetik pelajaran dari kisah perjuangan para pahlawan dan yang paling penting harus dapat menerapkan nilai kepahlawanan untuk memperkuat pendidikan karakter di abad ke-21 ini. Nilai kepahlawanan atau yang dikenal dengan patriotisme merupakan sikap berani, rela berkorban, dan pantang menyerah. Di Indonesia para pahlawan nasional seperti Jenderal Sudirman, Pangeran Diponegoro, Ki Hadjar Dewantara, Bung Tomo, R.A. Kartini, Soekarno, Muhammad Hatta dikenal karena jasanya yang begitu besar dalam merintis kemerdekaan Indonesia. Selain itu, kisah para pahlawan tersebut juga sering disampaikan dalam kegiatan pembelajaran di kelas. Namun, para pahlawan dari berbagai penjuru daerah yang juga memiliki peranan penting dalam memajukan bangsa Indonesia masih belum banyak diketahui oleh generasi muda. Oleh karena itu, dalam penelitian ini akan dikaji seorang sosok pahlawan dari Sidoarjo yang bernama Kyai Hasan Mukmin. Kisah perjuangan Kyai Hasan Mukmin masih orisinil belum ada yang mengeksplorasi nilai kepahlawanannya. Dengan demikian, melalui kajian ini diharapkan generasi muda akan dapat mengenal lebih mendalam sosok beliau.

Pahlawan adalah seseorang yang mempunyai sikap patriotisme dan patut dijadikan tauladan. Nilai kepahlawanan identik dengan sikap berani, rela berkorban, dan pantang menyerah. Selain itu, integritas nasionalistis yang melekat berupa (1) keuletan, (2) keberanian, (3) kerelaan untuk mengorbankan sesuatu, (4) bersifat ksatria, (5) memiliki tanggung jawab, (6) berwatak pemimpin, (7) teladan, (8) mencintai perdamaian, (9) heroik, (10) dapat mempelopori (Badrun, 2006, hal.32). 
Dalam Arsip (2014, hal.7-8) dijelaskan bahwa nilai kepahlawanan meliputi (1) berdedikasi tanpa pamrih, (2) memprioritaskan keperluan negaranya, (3) sukarela, (4) mencintai tanah tumpah darahnya, (5) percaya pada kemampuan sendiri, (6) pantang mundur, (7) jujur, (8) nasionalisme, (9) gigih, (10) berani, dan (11) ulet. Sependapat dengan itu, Nugraha (2019, hal.250) menyebutkan tujuh nilai-nilai dasar kepahlawanan yaitu (1) ikhlas berkorban, (2) cerdas, (3) teguh pendirian, (4) berani, (5) perwaktuan, (6) pencapaian luar biasa, dan (7) cinta tanah air.

Berdasarkan ketiga pendapat tersebut dapat disimpulkan bahwa terdapat enam belas nilai kepahlawanan. Keenam belas nilai kepahlawanan tersebut yaitu: (1) ulet artinya tidak mudah putus asa dalam berjuang; (2) berjiwa ksatria atau berani artinya tidak gentar terhadap segala bentuk ancaman; (3) rela berkorban artinya tidak takut kehilangan harta benda ataupun nyawa; (4) bertanggung jawab artinya selalu menyelesaikan semua amanat atau tugas; (5) berjiwa pemimpin artinya mampu memimpin anggota atau kelompoknya dengan baik; (6) teladan artinya segala bentuk sikap dan sifatnya dapat dijadikan panutan; (7) ikhlas artinya melakukan sesuatu tanpa pamrih; (8) jujur artinya dapat dipercaya; (9) gigih atau teguh pendirian artinya tidak mudah terpengaruh atau memiliki pendirian yang kuat sehingga tidak mudah terombang-ambing atau dipengaruhi; (10) cerdas artinya pandai dalam mengambil keputusan dan mencari solusi; (11) pantang mundur artinya tidak mudah menyerah; (12) berjiwa pelopor artinya mampu mengajak melakukan kebaikan; (13) cinta damai artinya tidak suka ada permusuhan atau pertikaian; (14) cinta tanah air atau nasionalisme artinya hormat dan mengabdi kepada bangsa dan negaranya, mengutamakan kepentingan negaranya dibandingkan kepentingan pribadi atau golongannya; (15) perwaktuan artinya menghargai dan memanfaatkan waktu sebaik mungkin; dan (16) pencapaian luar biasa artinya memiliki prestasi dan jasa yang banyak.

Nilai-nilai kepahlawanan tersebut digunakan untuk menanamkan pendidikan karakter. Karakter merupakan watak yang dimiliki oleh seseorang. Pembentukan karakter ini dipengaruhi oleh situasi dan kondisi lingkungan baik lingkungan keluarga, rumah, sekolah, dan masyarakat. Pendidikan karakter merupakan penentu baik buruknya identitas diri generasi muda yang nantinya akan melanjutkan era kepemimpinan bangsa. Apabila penerus bangsa berkarakter kuat dan berkualitas, negeri tersebut akan adil dan makmur. Begitupun sebaliknya jika penerus bangsa memiliki karakter yang lemah, negeri tersebut akan mudah terombang-ambing. Dengan demikian, hal itu sangat perlu diedukasikan sedari usia dini. Dalam lingkungan keluarga, orang tua dapat menanamkan karakter jujur, tanggung jawab, ikhlas kepada anaknya. Dalam lingkungan pendidikan formal, pimpinan sekolah, pengajar, dan staf berperan untuk menanamkan nilai-nilai karakter kepada peserta didiknya.

Pendidikan formal di sekolah berkontribusi besar dalam menanamkan pendidikan karakter untuk anak. Dalam lingkungan sekolah nilai moral menjadi prioritas utama yang diberikan untuk peserta didik. Hal ini dikarenakan, penguatan nilai tersebut dan sikap saling menghormati independensi antarwarga sekolah merupakan cerminan pendidikan karakter pada lingkungan sekolah. Apabila digabungkan maka akan menjadi pendidikan karakter berbasis pengajaran (A. Doni, 2007, hal.135). 
Nilai, upaya, dan sistem menurut Samani dan Hariyanto (2011, hal.45-46) merupakan tiga kunci utama untuk menumbuhkan pendidikan karakter dalam jiwa peserta didik. Pertama nilai, berupa pendidikan budi pekerti, moral, dan watak yang digunakan untuk mengajarkan peserta didik agar dapat menentukan hal positif dan negatif, sikap terpuji dan tercela, serta cara mengaplikasikan perbuatan yang menguntungkan dirinya dan tidak merugikan orang lain dalam menjalani hidupnya dengan tulus ikhlas. Kedua upaya, maksudnya agar peserta didik dapat merealisasikan segala bentuk nilai karakter di kehidupannya, memerlukan dukungan utama dari orang tua dan pengajar secara konsisten. Ketiga sistem, yaitu segala unsur penanaman karakter harus dilakukan secara utuh. Unsur tersebut terdiri dari wawasan, pemahaman, perbuatan yang harus diterapkan oleh peserta didik untuk berinteraksi dengan penciptanya, dirinya sendiri, peserta didik lainnya, dan lingkungannya berada.

Nilai kepahlawanan dalam kisah pejuang dapat dimanfaatkan sebagai bahan ajar. Bahan ajar merupakan serangkaian materi yang berfungsi sebagai pendamping untuk pendidik dalam mengajar agar memudahkan peserta didik memahami sasaran yang harus dicapainya dalam kegiatan pembelajaran. Menurut Nurjaya (2012, hal.104) bahan ajar disajikan dengan runtut dan terorganisir dalam bentuk sub-sub materi yang saling berkaitan sebagai suatu wawasan. Lebih lanjut, Aisyah, Noviyanti, dan Triyanto (2020, hal.63) menjelaskan bahwa dalam kegiatan belajar-mengajar bahan ajar diperlukan sebagai pangkal materi bagi pengajar.

Dari kedua argumen tersebut dapat dipahami bahwa suatu wawasan dalam bentuk sub-sub materi dengan disajikan secara runtut digunakan dalam kegiatan belajarmengajar di kelas sebagai pendukung bagi pengajar. Bahan ajar di antaranya dapat berwujud tulisan atau audio. Tulisan berupa cerita narasi yang berisi hasil eksplorasi nilai kepahlawanan untuk menguatkan pendidikan karakter merupakan wujud yang digunakan dalam penelitian.

Narasi menurut Keraf (1991, hal.36) adalah gambaran jelas suatu peristiwa yang telah berlangsung dalam suatu bentuk wacana sehingga pembaca dapat mengetahuinya. Lebih lanjut, Ningsi (2017, hal.48) menjelaskan bahwa narasi mementingkan urutan kronologis dalam menyampaikan peristiwa yang dialami tokoh dalam kurun waktu tertentu melalui bentuk wacana. Sehubungan dengan itu, Fransiska (2017, hal.70-71) mengemukakan bahwa narasi merupakan suatu karangan yang ketika pembaca membacanya dapat merasakan peristiwa itu seolah-olah mengalaminya sendiri. Dari ketiga penjelasan tersebut dapat dipahami pada intinya wacana yang berisi peristiwa sesuai urutan waktu yang terjadi pada seseorang disebut narasi.

Tujuan penelitian ini sebagai berikut. Pertama, untuk mendeskripsikan nilai kepahlawanan dalam diri Kyai Hasan Mukmin. Kedua, pemanfaatan nilai kepahlawanan Kyai Hasan Mukmin sebagai bahan ajar pendidikan karakter. Penelitian dilakukan untuk memperkuat konsep tentang nilai kepahlawanan yang tercermin dalam diri Kyai Hasan Mukmin dan menjadi referensi terhadap penelitian selanjutnya yang ingin meneliti nilai kepahlawanan sebagai bahan ajar pendidikan karakter.

Penelitian terdahulu yang relevan dengan penelitian ini dilakukan oleh Efendi (2020) berjudul "Nilai Karakter dalam Novel Biografi Hatta: Aku Datang karena Sejarah 
Karya Sergius Sutanto” yang diterbitkan jurnal Pendidikan Karakter pada April 2020. Dalam hasil penelitiannya ditemukan nilai-nilai karakter kemandirian, semangat kebangsaan, cinta tanah air, cinta damai, gemar membaca, dan kejujuran. Kemudian, juga dilakukan oleh Andina dkk (2020) berjudul "Nilai Kepahlawanan dalam Serat Kridawasita (Kajian Filologi)" yang diterbitkan jurnal Alfabeta: Jurnal Bahasa, Sastra, dan Pembelajarannya pada 2020. Dalam hasil penelitiannya terdapat 6 indikator nilai kepahlawanan dalam Serat Kridhawasita di 9 pupuh tembang. Kedua penelitian tersebut memiliki kesamaan dengan penelitian ini yaitu menganalisis nilai kepahlawanan sedangkan yang membedakan adalah objek yang dipilih.

\section{METODE PENELITIAN}

Penelitian ini menggunakan pendekatan kualitatif deskriptif. Informasi dari narasumber tentang perjuangan Kyai Hasan Mukmin merupakan data penelitian. Informan dalam penelitian yaitu penjaga makam dan seniman lokal dari daerah Sidoarjo. Teknik pengumpulan data yang digunakan wawancara dan dokumentasi. Keduanya berperan untuk mengumpulkan data penelitian (1) nilai kepahlawanan yang ada dalam diri Kyai Hasan Mukmin dan (2) pemanfaatan nilai kepahlawanannya sebagai bahan ajar pendidikan karakter.

Analisis deskriptif merupakan teknik penganalisisan data yang diterapkan dalam penelitian. Tahap-tahap penganalisisan data yang dilakukan sebagai berikut. Pertama, mendengarkan hasil video dokumentasi wawancara dari kedua narasumber. Kedua, mentranskrip data hasil video dokumentasi wawancara dari kedua narasumber. Hal ini dilakukan peneliti untuk memudahkan analisis data. Ketiga, melakukan pengecekan hasil transkripsi data dengan memutar video dokumentasi wawancara berulang kali. Keempat, melakukan reduksi data dengan memfokuskan pada (1) nilai kepahlawanan yang ada dalam diri Kyai Hasan Mukmin dan (2) pemanfaatan nilai kepahlawanannya sebagai bahan ajar pendidikan karakter. Kelima, data dianalisis sesuai dengan fokus penelitian.

Pengecekan keabsahan temuan dilakukan ketika data penelitian sudah selesai diolah. Kegiatan ini dilakukan agar analisis data dapat dipertanggungjawabkan keabsahannya. Pengecekan keabsahan temuan dilakukan dengan triangulasi yaitu dengan cara melakukan pengecekan ulang terhadap hasil transkripsi data penelitian dari dua narasumber. Kemudian, melakukan konsultasi dengan pakar.

Untuk lebih mempermudah pemaparan, terdapat beberapa istilah yang terkait dengan penelitian ini. Pertama, nilai kepahlawanan merupakan hasil eksplorasi sikap patriotisme yang dimiki oleh Kyai Hasan Mukmin. Kedua, pendidikan karakter berupa penanaman nilai moral dan budi pekerti.

\section{PEMBAHASAN}

\section{Hasil nilai kepahlawanan yang ada dalam diri Kyai Hasan Mukmin}

Dari hasil eksplorasi kisah perjuangan Kyai Hasan Mukmin, nilai kepahlawanan yang ditemukan yaitu ulet, rela berkorban, berjiwa pemimpin, teladan, gigih, pantang mundur, dan berjiwa pelopor. Berikut dideskripsikan pemaparan hasil eksplorasi nilai kepahlawanan Kyai Hasan Mukmin daerah Sidoarjo. 


\section{Ulet}

Kyai Hasan Mukmin memiliki karakter yang ulet yaitu tidak mudah putus asa dalam berjuang melawan tentara Belanda untuk membebaskan lahan pertanian yang sebagian besar ditanami tebu. Eksplorasi nilai kepahlawanan tersebut ditemukan dalam data berikut.

(01)

N2 : Karena pada... peristiwa 10 November, 50 tahun berikutnya.

$\mathrm{P} \quad$ : Muncul lagi...

N2 : Muncul sebuah pasukan, muncul sebuah pasukan dari arah, dari arah ini, dari arah... Mojokerto. Dari arah Mojokerto, namanya pasukan kalau gak salah pasukan Suro Djoyo Diningrat gitu ya. Lah Suro Djoyo Diningrat nah itu disinyalir pasukan dari Kyai Hasan Mukmin.

Dari data (01) tersebut dapat diketahui bahwa Kyai Hasan Mukmin meski sempat mengalami kekalahan dalam berperang melawan tentara Belanda, beliau tetap tidak putus asa dan berjuang kembali dengan membentuk pasukan baru setelah 50 tahun kemudian. Pasukan tersebut datang dari arah Mojokerto.

\section{Rela berkorban}

Kyai Hasan Mukmin memiliki karakter rela berkorban yaitu tidak takut kehilangan. Beliau tidak takut kehilangan nyawanya, keluarganya, dan harta bendanya ketika melawan tentara Belanda. Eksplorasi nilai kepahlawanan tersebut ditemukan dalam data berikut.

P : Akhirnya dari Kyai Hasan Mukminnya sendiri e... merasa itu merupakan suatu permasalahan ya Om ya untuk masyarakat sekitarnya ya.

N2 : Iya, menjadi permasalahan tersendiri. Apalagi pada saat itu e... untuk memenuhi kebutuhan pokok saja saat itu sangat sulit. Sangat sulit bagi masyarakat sekitar. Sehingga nah akhirnya pecahlah di tahun kalau dicatatannya milik Sidoarjo itu tahun 1904 yang tercatat di Sidoarjo.

$\mathrm{P} \quad$ : Iya.

N2 : Kalau beberapa sih ada yang bicara 19, 1901, 1902, atau 03. Antara itu lah. Tapi kalau dicatatan Sidoarjo 1904. E... karena keyakinan itulah, masalah keyakinan sehingga timbul kenekatan. Kalau saya pikir timbul kenekatan. Dengan berbekalkan e... rasa yakin mereka untuk berjuang akhirnya timbul nekat. Rasa nekat untuk, untuk melawan. Hingga pada hari ke-12 jadi istilahnya pada bulan Maulud hari ke-12 pas waktu e... hari lahirnya Nabi Muhammad waktu itu jadi itulah dijadikan e... titik tolak untuk melawan. Memang, pada saat itu mereka mampu untuk menguasai e... kawadanan kalau dulu kawadanan sekarang kecamatan. Kecamatan Gedangan. Kecamatan. Mereka mampu untuk beberapa jam menguasai kecamatan Gedangan bahkan diceritakan e... apa itu namanya menawan wedono atau camat Gedangan waktu itu. Tapi, bagaimanapun juga bala bantuan dari Surabaya, dari Sidoarjo, bala bantuan polisi-polisi Hindia-Belanda itu sangat gencar dan akhirnya Kyai Hasan Mukmin pada pecah. Pecahnya perang yang kedua e... terdesak mundur dan gugur di Sumantoro. Untuk bagi penduduk di Sumantoro mempercayai bahwa Kyai Hasan Mukmin pada saat itu gugur di desa Sumantoro. Walaupun banyak sekali yang yang secara istilahnya kalau udah ngomong cerita rakyat itu hanya bicara mistifikasi. 
Dari data (02) tersebut dapat diketahui bahwa Kyai Hasan Mukmin melakukan perlawanan. Beliau dan para santri berusaha mengambil alih untuk menguasai Kecamatan Gedangan. Namun, pada akhirnya beliau harus gugur kehilangan nyawanya.

N2 : Kalau orang-orang Sumantoro dari... dari juru kunci makam yang ada di Sumantoro sini itu ada putrinya yang ikut serta bertempur dengan ayahnya yaitu namanya Markamah. Bernama Markamah. Itu putri pertamanya. Dia ikut bertempur. Pada saat itu e... Markamah berumur sekitar belasan, 17-an sekitar segitu. Nah, diceritakan oleh orang-orang sini, oleh Pak Saud waktu itu sebagai juru kuncinya Bapak Saud sebagai juru kuncinya. Itu Markamah itu diceritakan muksa istilahnya orang sini muksa atau menghilang ketika e... pasukan dari Sumantoro e... pasukan Kyai Hasan Mukmin itu mundur ke Sumantoro kembali terdesak mundur ke Sumantoro dan polisi-polisi Hindia Belanda saat itu me... apa namanya... mengejar sampai ke Sumantoro ketika terjadi pertempuran kembali dan rumah-rumah yang ada di Sumantoro ini di karangabang istilahnya atau dibakar habis, saat itu Kyai Hasan Mukmin apa namanya Markamah diceritakan muksa, hilang. Dan memang saat itu. Banyak sekali polisi-polisi juga polisi Hindia Belanda mencari ini, mencari keluarga-keluarganya. Keluarga-keluarga beliau. Ya mungkin diharapkan tidak muncul kembali, pemberontakan-pemberontakan lagi.

$\mathrm{P} \quad$ : Pemberontakan-pemberontakan lagi.

N2 : Dan nah itu dan kemungkinan memang entah benar-benar Kyai Hasan Mukmin saat itu sedo atau Kyai Hasan Mukmin saat itu memang disembunyikan atau ada orang yang bersedia untuk menggantikan dirinya untuk sedo begitu kan sebagai tameng gak ada yang tahu.

Dari data (03) tersebut dapat diketahui bahwa Kyai Hasan Mukmin kehilangan putrinya, keluarganya, rumahnya karena telah melawan tentara Belanda. Mereka membunuh keluarganya dan membakar rumahnya agar tidak berani melakukan perlawanan kembali.

\section{Berjiwa pemimpin}

Kyai Hasan Mukmin berjiwa pemimpin. Beliau adalah tokoh masyarakat yang dijadikan panutan dan memimpin para santri untuk melawan tentara Belanda. Eksplorasi nilai kepahlawanan tersebut ditemukan dalam data berikut.

N2 : E... sebenernya ada dua tokoh yang saya angkat di naskah itu yaitu putrinya Markamah dan Kyai Hasan Mukmin. Bagaimana seorang ayah itu ingin mengentaskan, mengentaskan kehidupan, kehidupan santri-santrinya, keluarganya, dari jaman saat itu di mana e... jaman yang serba mepet orang tidak bisa bergerak apaapa, pajak sangat tinggi tidak bisa ini, tidak bisa bercocok tanam dengan enak dan bagaimana mengentaskan itu semua. Nah itu adalah keinginan seorang ayah dan sebagai seorang tokoh masyarakat. Tapi juga sebagai seorang ayah ketika e... seorang anak Markamah untuk bermaksud e... apa namanya membantu ayahnya otomatis seorang ayah seorang perempuan istilahnya e... ya pastilah namanya ayah tidak tega melihat anaknya.

$\mathrm{P} \quad$ : Menderita.

N2 : Nah untuk ikut berperang. Apa namanya me...

$\mathrm{P}$ : Memegang pedang.

N2 : Memegang pedang, memegang senjata tajam, tangan harus dilumuri darah musuhmusuh. Itu dia tidak tega tapi bagaimanapun juga ayah pasti ketika menyampaikan sebuah apa namanya menyampaikan sebuah nasehat, sebuah pembelajaran kepada santri-santrinya otomatis keluarganya, anak-anaknya pasti mendengar. 
Dari data (04) tersebut dapat diketahui bahwa Kyai Hasan Mukmin dapat mengayomi para santrinya. Beliau berusaha mencarikan solusi bagaimana mengakhiri masa penjajahan Belanda yang memberatkan keluarganya dan para santrinya. Mereka harus membayar pajak dan kehilangan lahan pertanian untuk menanam kebutuhan pokok. Lahan pertanian banyak ditanami tebu untuk diolah menjadi minuman keras.

\section{Teladan}

Kyai Hasan Mukmin adalah sosok yang teladan. Beliau banyak dijadikan panutan oleh para santrinya. Eksplorasi nilai kepahlawanan tersebut ditemukan dalam data berikut.

N2 : Karakternya. Karakternya orangnya tegas, tapi penuh lembut pada e... keluarganya e... sifat ngemong terus e... memberi inspirasi, memberi inspirasi dan juga apa namanya bisa meyakinkan istilahnya ya itulah kekuatan seseorang ketika, ketika memiliki apa namanya santri yang banyak kenapa santri itu bisa hadir. Bisa hadirnya seperti sebuah keyakinan, memberikan sebuah keyakinan pada orang-orang pada saat itu ketika ke mana sih saya harus berpegang. E... ketika tokoh seperti Kyai Hasan Mukmin memberikan sebuah keyakinan, yakin bahwa kita bisa berubah bahwa perjuangan ini bisa, bisa memberikan sebuah timbal balik dan memang saat itu e... bagi mana bagi orang-orang sini orang-orang Sidoarjo, orang-orang pemerintah Hindia-Belanda kaget karena sudah beberapa puluh tahun tidak ada pemberontakan lagi tiba-tiba ada sebuah pemberontakan saat itu. Itu menjadi kaget. Oh ternyata masih ada daya juangnya.

$\mathrm{P} \quad$ : Iya.

N2 : Masih ada daya juangnya, iya. Itu yang masih daya juang itulah.

$P \quad$ : Daya juangnya berarti tinggi.

N2 : Iya daya juangnya tinggi.

Dari data (05) tersebut dapat diketahui bahwa Kyai Hasan Mukmin memiliki banyak santri karena beliau dapat membimbing, memberikan inspirasi, dan memberikan keyakinan ketika mereka tidak memiliki pedoman hidup dan dilema akan apa yang hendak dilakukan.

\section{Gigih}

Kyai Hasan Mukmin adalah sosok yang gigih. Beliau tidak mudah terpengaruh karena memiliki keyakinan yang tinggi dalam dirinya. Eksplorasi nilai kepahlawanan tersebut ditemukan dalam data berikut.

(06)

P : Iya itu secara tidak langsung Om berarti menanamkan nilai-nilai apa saja sifat-sifat dan karakter dari Kyai Hasan Mukmin.

$\mathrm{N} 2$ : Iya.

$\mathrm{P} \quad$ : Kemudian, Markamah dan santri-santrinya.

N2 : Iya minimal adalah mereka selain paham tentang, tentang apa namanya tentang e... sejarahnya tapi juga nilai-nilai karakter dari kedua tokoh itu. Yaitu Kyai Hasan Mukmin dan Markamah itu. Kyai Hasan Mukmin dengan e... rasa keyakinannya yang sangat tinggi. Markamah rasa cintanya pada dengan Sang Ayah dan e... rasa pedulinya kepada bangsanya. Itu e... saya coba tekankan di situ. Pada para pemain pada saat itu.

$\mathrm{P} \quad$ : Dan para pemainnya juga mendalami perannya itu Om ya.

$\mathrm{N} 2 \quad$ : Iya. 
Dari data (06) tersebut dapat diketahui bahwa Kyai Hasan Mukmin memiliki rasa keyakinan yang sangat tinggi. Beliau tidak mudah goyah dan yakin dapat merdeka dari penjajahan Belanda.

\section{Pantang mundur}

Kyai Hasan Mukmin adalah sosok yang tidak mudah menyerah. Beliau pantang mundur saat melawan tentara Belanda. Eksplorasi nilai kepahlawanan tersebut ditemukan dalam data berikut.

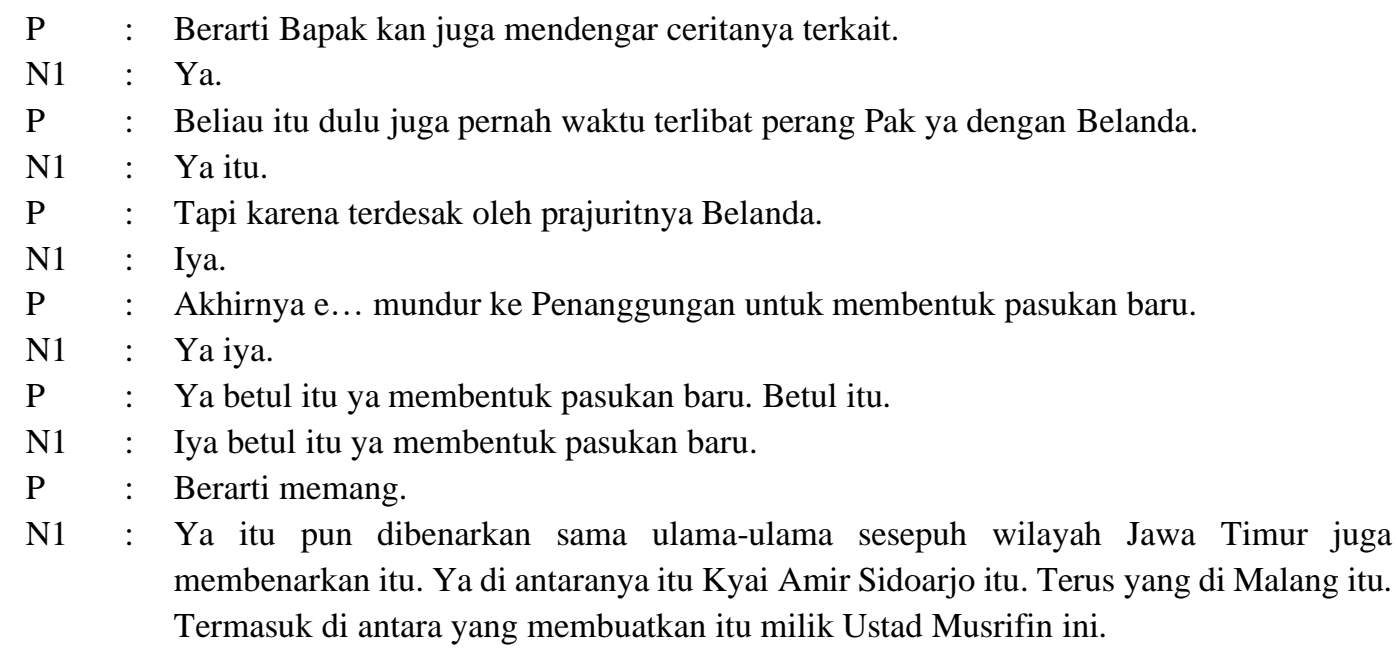

Dari data (07) tersebut dapat diketahui bahwa Kyai Hasan Mukmin meskipun sempat mengalami kekalahan dalam melawan tentara Belanda, beliau tidak mudah menyerah. Beliau membentuk pasukan baru dan menyusun siasat untuk memberikan serangan balasan kepada tentara Belanda.

N2 : E... adalah rasa daya juang yang tinggi, tidak mengenal menyerah, kemudian kalau orang Jawa bilang itu sopo bakal temen bakal tinemu. Siapa yang bersungguh-sungguh akan menemukan sesuatu. Intinya gitu. Kemudian, e... rasa sayang kepada keluarga. Rasa sayang kepada sesama. Saling e... saling peduli pada sesama itu juga. Itu yang itu yang bisa kita dapat di e... di cerita Kyai Hasan Mukmin itu dalam perjuangannya.

$\mathrm{P} \quad$ : Berarti untuk anak-anak SD itu harus terus berjuang ya Om?

$\mathrm{N} 2 \quad: \quad$ Iya.

Dari data (08) tersebut dapat diketahui bahwa Kyai Hasan Mukmin tidak mengenal kata menyerah dalam melawan tentara Belanda. Beliau terus berjuang untuk mendapatkan kebebasan bagi kaumnya.

\section{Berjiwa pelopor}

Kyai Hasan Mukmin berjiwa pelopor. Beliau mampu mengajak kebaikan. Eksplorasi nilai kepahlawanan tersebut ditemukan dalam data berikut. 
(09)

P : E... begini Om yang pertama mau saya tanyakan. E... dari sudut pandangnya Om ini kisah hidupnya Kyai Hasan Mukmin itu bagaimana Om?

N2 : E... menurut... jadi bagaimanapun juga apa yang saya sampaikan ini ya dari sumber dalam artian hm... dari masyarakat sekitar apa yang dipercaya oleh masyarakat sekitar. Di mana Kyai Hasan Mukmin pernah hidup. Kalau dari sumber itu menceritakan, e... bahwa Kyai Hasan Mukmin itu adalah seseorang, seseorang yang berasal dari bekas Laskar Diponegoro. Itu yang dipercaya oleh, oleh masyarakat e... di dusun Sumantoro di desa Plumbungan e... Sidoarjo. E... Kyai Hasan Mukmin itu mendirikan semacam e... istilahnya itu pengajian. Istilahnya itu pengajian atau sebuah, sebuah aliran torekhoh, aliran torekhoh yang e... di mana di sini lebih pada e... sebuah keikhlasan sepenuhnya oleh Sang Maha Pencipta di situ. Keyakinan yang sepenuhnya e... pada Sang Maha Pencipta. Di mana nanti pada suatu saat ketika dalam pada sebuah cerita perjuangan beliau itu e... keyakinan itu lah yang menjadi sebuah motor penggerak dahyat pada saat itu untuk melakukan sebuah perlawanan. Nah, e... Kyai Hasan Mukmin ini memiliki banyak santri. Tapi dalam artian di sini Kyai Hasan Mukmin tidak mendirikan pondok ya istilahnya. Tidak mendirikan pondok. Jadi, semacam tempat untuk pengajian begitu. Untuk mengaji, untuk mengkaji sebuah kitab, mengkaji sebuah kehidupan, mengkaji peristiwa-peristiwa perkembangan e... jaman di di mana pada saat itu memasuki abad e... 19 ya... Abadabad yang ini, abad-abad politik etis oleh pemerintah Hindia Belanda saat itu di mana e... permasalahan tanahlah yang menjadi sangat krusial pada saat itu. Di mana para petani e... tidak memiliki hak yang sangat e... mencukupi atau memadai bagi kehidupan mereka sehingga e... pada saat itu menjadi keresahan. Keresahan para santri, keresahan masyarakat e... di mana pada saat itu sawah-sawah yang ada di Sidoarjo ini tiga perempatnya harus ditanami oleh tumbuhan tebu dan seperempatnya boleh ditanami oleh e... tumbuhan produktif seperti padi dan lainnya. Tapi itu sangat tidak adil. Belum lagi e... belum lagi paksaan untuk bekerja e... di pabrik tebu ketika masa giling. Ketika ada masa giling. Itu sangat memberatkan sekali. Nah itu menjadi, menjadi apa namanya sebuah kajian-kajian di tingkatan e... tempat pengajian Kyai Hasan Mukmin itu sendiri. Dan itu menjadi e... sebuah trigger atau pemicu bagaimana mereka harus melawan. Gitu.

Dari data (09) tersebut dapat diketahui bahwa Kyai Hasan Mukmin adalah bekas Laskar Diponegoro. Beliau menganut aliran torekhoh yang mengajarkan keikhlasan. Beliau sering mengadakan pengajian, melakukan pengkajian sebuah kitab, kehidupan, dan peristiwa perkembangan zaman dengan para santrinya. Dalam setiap pertemuan dengan para santrinya, Kyai Hasan Mukmin memotivasi untuk melakukan perlawanan agar mereka tidak hidup dalam penjajahan lagi.

\section{Hasil pemanfaatan nilai kepahlawanan Kyai Hasan Mukmin sebagai bahan ajar pendidikan karakter}

Hasil eksplorasi nilai kepahlawanan yang ditemukan dalam diri Kyai Hasan Mukmin dimanfaatkan sebagai bahan ajar berupa cerita narasi. Bahan ajar tersebut nantinya dapat digunakan untuk menanamkan pendidikan karakter kepada mahasiswa melalui kegiatan perkuliahan. Berikut cerita narasi dengan judul "Kyai Hasan Mukmin, Pahlawan dari Sidoarjo".

Kyai Hasan Mukmin merupakan seseorang yang menganut aliran tharekat Qodiriyah Naqsabandiyah yang menanamkan keikhlasan kepada Tuhan Yang Maha Esa 
dalam dirinya. Beliau adalah bekas Laskar Diponegoro. Pada tahun 1903 di Kabupaten Sidoarjo terjadi penjajahan Belanda yang menerapkan sistem Tanam Paksa. Masyarakat diminta untuk menanam tebu di ladang pertaniannya dan membayar pajak yang tinggi kepada pemerintah Belanda. Hasil dari panen tebu tersebut diolah menjadi minuman keras. Masyarakat menderita kelaparan karena lahan pertanian terbatas untuk ditanami kebutuhan pokok. Hal inilah yang membuat Kyai Hasan Mukmin prihatin dan ingin membebaskan masyarakat Sidoarjo dari penjajahan Belanda.

Kyai Hasan Mukmin sering mengadakan pengajian dan memberikan pengayoman kepada santri-santri yang hadir ke rumahnya. Semakin lama jumlah santri yang datang kian banyak. Beliau menuntun para santri kala mereka dilema harus melakukan apa dan tidak memiliki tujuan hidup yang jelas karena penjajahan Belanda. Beliau selalu memberikan inspirasi dan motivasi agar para santri mau berjuang untuk mendapatkan kebebasan agar hidup layak.

Seiring berjalannya waktu karena penjajahan yang dilakukan Belanda semakin memberatkan masyarakat, Kyai Hasan Mukmin menyusun siasat dengan para santrinya untuk melakukan perlawanan kepada tentara Belanda. Setelah semua persiapan selesai, bertepatan pada hari ke-12 Bulan Maulud Nabi tanggal 27 Mei 1903 Kyai Hasan Mukmin memimpin serangan untuk mengambil alih Kecamatan Gedangan yang pada masa itu dipimpin oleh Bupati bentukan Belanda. Pada awalnya, Kyai Hasan Mukmin dan para santri berhasil menduduki Kecamatan Gedangan. Namun, bala bantuan tentara Belanda datang dengan jumlah yang lebih banyak. Akhirnya, para santri banyak yang terbunuh dan Kyai Hasan Mukmin mengalami luka yang parah. Akan tetapi, dengan semangatnya yang membara Kyai Hasan Mukmin terus berjuang hingga beliau akhirnya terdesak dan para santri yang masih selamat membawa beliau melarikan diri ke Gunung Penanggungan.

Para tentara Belanda terus mengejar dan mencari Kyai Hasan Mukmin sampai di Dusun Sumantoro Kecamatan Sukodono tempat beliau tinggal. Mereka membunuh keluarganya dan keluarga para santrinya yang memberontak. Mereka juga membakar rumah orang-orang yang ikut berjihad bersamanya. Hal ini dilakukan agar masyarakat takut dan tidak ada pemberontakan lagi kepada pemerintah Belanda. Putrinya Markamah yang ikut berjuang bersama Ayahnya pun juga menghilang. Melihat peristiwa ini, santri Kyai Hasan Mukmin banyak yang menyamar menjadi beliau untuk mengelabuhi tentara Belanda agar tidak mencarinya lagi.

Setelah 40 tahunan berlalu semenjak peristiwa itu, Kyai Hasan Mukmin muncul kembali ketika pemimpin besar Nahdlatul Ulama Kyai Hayim Asy'ari ditahan karena menolak perintah pada penjajahan Jepang dan memberikan fatwa haram terhadap perintah menundukkan badan 90 derajat menghadap ke arah Tokyo sebagai bentuk penghormatan kepada Raja Jepang. Pada tanggal 10 November 1945 di seluruh penjuru negeri melakukan perlawanan kepada tentara Jepang untuk meraih kemerdekaan. Di Surabaya perlawanan dipimpin oleh Bung Tomo. Untuk membantu memenangkan pertempuran tersebut, pasukan Kyai Hasan Mukmin yang bernama Suro Diro Joyo Jayaningrat Lebur Dhening Pangastuti datang bergabung dalam perang dahsyat merebut kemerdekaan. 
Pada akhirnya, perlawanan tersebut memperoleh kemenangan. Mereka berhasil menduduki Surabaya dan daerah di sekitarnya. Satu tahun kemudian, pada tanggal 8 Februari 1946 Kyai Hasan Mukmin pun gugur dan dimakamkan di kompleks pemakaman bersama leluhurnya Sayyid Suro Sulaiman di Desa Balungdowo Kecamatan Candi Kabupaten Sidoarjo. Makam tersebut disahkan sebagai tempat peristirahatan terakhir Kyai Hasan Mukmin bersama istrinya oleh Bupati Sidoarjo. Mengingat dulu banyak santri yang menyamar menjadi beliau sehingga makamnya ada banyak diberbagai tempat. Kyai Hasan Mukmin dianggap sebagai sosok pahlawan bagi masyarakat Sidoarjo atas perjuangannya dan dedikasinya.

\section{Pembahasan nilai kepahlawanan yang ada dalam diri Kyai Hasan Mukmin}

Dari paparan hasil menunjukkan bahwa di dalam diri seorang pejuang memiliki nilai-nilai kepahlawanan yang dapat dijadikan pembelajaran bagi generasi penerusnya. Seperti yang disampaikan oleh Farhat (2020, hal.28) dari cerita perjuangan para pahlawan dalam merebut kemerdekaan dan mempertahankan kemerdekaan bangsa dapat diperoleh pelajarannya. Ketika para pahlawan melawan penjajah banyak hal yang harus disiapkan dan dikorbankan. Apalagi dengan peralatan tempur yang tidak sepadan dengan musuh mereka tidak gentar dan tetap semangat. Pada zaman penjajahan Belanda dan Jepang para pejuang hanya menggunakan bambu runcing dan pedang untuk melawan sedangkan tentara Belanda dan Jepang sudah menggunakan senapan. Dengan demikian, banyak yang kehilangan nyawa dalam pertempuran karena untuk membunuh musuh pejuang harus mendekat. Namun, semua itu tetap dilakukan karena para pejuang mencintai tanah airnya, rela mengorbankan nyawanya, dan siap untuk senantiasa membela negaranya. Nilai-nilai ini identik dengan sikap kepahlawanan dan keberanian (Istiqamah, 2020, hal.56).

Kyai Hasan Mukmin merupakan salah satu pejuang Islam yang berusaha membebaskan masyarakat Sidoarjo dari penjajahan Belanda. Beliau sosok yang mengayomi para santri ketika tidak memiliki tujuan hidup dengan ikhlas sehingga semakin lama jumlah santrinya semakin banyak. Hal ini terlihat dalam data (04) di paparan hasil. Beliaulah yang memimpin pemberontakan melawan tentara Belanda. Saraswati (2016, hal.158) menyebutkan ada 8 prinsip yang mendasari karakteristik seorang pemimpin. Salah satu karaktersitik tersebut ada dalam diri Kyai Hasan Mukmin yaitu membawa energi yang positif didasarkan pada keikhlasan.

Untuk memperoleh sebuah kebebasan membutuhkan pengorbanan. Kyai Hasan Mukmin rela mengorbankan harta benda dan keluarganya karena keputusannya melawan tentara Belanda. Hal ini terlihat dalam data (02) dan (03) di paparan hasil. Arifin (2020, hal.31) menjelaskan nilai rela berkorban mencerminkan sikap seseorang dalam berkhidmat dengan mengedepankan kepentingan orang lain daripada kepentingan diri sendiri.

Kyai Hasan Mukmin melakukan perlawanan dengan para santri karena sudah tidak sanggup melihat masyarakat daerah Sidoarjo yang harus membayar pajak dan mengalami kesulitan bahan pangan. Meski mendapatkan kekalahan dalam perlawanannya, beliau tetap pantang mundur, membentuk pasukan baru, dan menyusun siasat untuk melakukan serangan balik. Hal ini terlihat dalam data (01) dan (07) di paparan hasil. Nilai rela 
berkorban tersebut tidak hanya ada pada diri Kyai Hasan Mukmin saja. Khoirurrohman (2020, hal.17) menemukan nilai rela berkorban dalam diri Pangeran Samparwadi ketika menyelesaikan kerusuhan dan memberantas kejahatan di kerajaan Mataram. Kemudian, Achmad Soebardjo yang rela berkorban untuk bangsa Indonesia dalam upaya membantu memerdekakan Indonesia dari penjajahan Jepang (Hadiah, 2020, hal.86).

Kyai Hasan Mukmin adalah sosok yang teladan. Beliau banyak dijadikan panutan karena dapat membimbing, memberikan inspirasi, dan keyakinan pada para santrinya bahwa suatu saat kebebasan akan didapatkan. Hal ini terlihat dalam data (05) di paparan hasil. Nilai keteladanan ditemukan juga dalam diri Raden Patah. Ada tiga aspek keteladanan yaitu sikap tolerasi (saling menghargai pendapat dan perbedaan), kerukunan (tidak saling memusuhi), dan patuh kepada orang tua (Amrulloh, 2020, hal.95). Untuk mencapai sesuatu yang diinginkan, harus ulet yaitu tidak mudah putus asa dalam berjuang. Kyai Hasan Mukmin terus berjuang sampai usianya tidak lagi muda. Segala perjuangannya tidak sia-sia karena pada akhirnya Sidoarjo mendapatkan kebebasan. Putro (2020, hal.10) menyampaikan bahwa kerja keras akan menuaikan hasil yang hebat. Oleh karena itu, jika dalam usaha tersebut mendapatkan kegagalan harus tetap bersemangat mencapainya.

\section{Pembahasan pemanfaatan nilai kepahlawanan Kyai Hasan Mukmin sebagai bahan ajar pendidikan karakter}

Berdasarkan paparan hasil menunjukkan bahwa dalam diri seorang pejuang terdapat nilai-nilai kepahlawanan yang dapat dijadikan panutan. Nilai kepahlawanan tersebut dapat dimanfaatkan sebagai bahan ajar pendidikan karakter. Setiawan (2017, hal.150) menjelaskan bahwa karakter tidak terlepas dari nilai karakter yang telah digagas untuk kembali diajarkan pada generasi muda. Dengan demikian, untuk memperkuat karakter generasi muda, dapat ditanamkan nilai kepahlawanan yang ditemukan dalam diri Kyai Hasan Mukmin. Karakter atau yang disebut juga watak adalah sesuatu yang berpengaruh dalam kehidupan seseorang. Sedari kecil seorang anak baiknya diajarkan nilai-nilai karakter agar ketika beranjak dewasa tidak mengikuti arus perkembangan zaman yang negatif. Sejatinya karakter itu dibentuk melalui tiga medium seperti keluarga, lingkungan sosial, dan sekolah (Bulan, 2020, hal.33). Keluarga merupakan tahap awal karakter anak terbentuk. Orang tua dapat mulai mengajarkan anaknya untuk bersikap religius, jujur, disiplin, dan tanggung jawab. Lingkungan sosial akan mulai mempengaruhi karakter anak. Terakhir, sekolah berkontribusi besar dalam menanamkan pendidikan karakter kepada anak.

Untuk menanamkan pendidikan karakter, salah satu sarana yang dapat digunakan yaitu melalui sastra. Di dalam karya sastra, baik secara langsung dan tidak langsung mengandung nilai-nilai tersebut. Sastra adalah cerminan dari kehidupan manusia. Melalui bahan ajar yang sesuai, nilai pendidikan karakter dapat diimplisitkan dalam pembelajaran di kelas (Windiatmoko, 2016, hal.16).

Pada umumnya, bahan ajar dapat berwujud tertulis dan audio. Nilai kepahlawanan yang telah ditemukan dalam diri Kyai Hasan Mukmin disajikan dalam bahan ajar tertulis. Selain untuk menanamkan nilai kepahlawanan juga untuk membiasakan budaya literasi 
baca kepada mahasiswa. Agar setiap peristiwa yang disampaikan runtut dan jelas maka menggunakan tulisan narasi. Hal ini dikarenakan, pada narasi terdapat peristiwa atau kejadian dalam satu urutan waktu. Dalam kejadian itu, ada tokoh yang menghadapi suatu konflik (Rahmadani, 2017, hal.20). Hal ini terlihat dalam cerita narasi berjudul "Kyai Hasan Mukmin, Pahlawan dari Sidoarjo" di paparan hasil. Peristiwa yang disajikan yaitu perjalanan Kyai Hasan Mukmin dalam memperoleh kebebasan. Tokohnya adalah Kyai Hasan Mukmin dan permasalahan yang dihadapi olehnya yaitu masa penjajahan Belanda. Lebih lanjut, Gusar (2019, hal.207) menjelaskan bahwa narasi bertujuan untuk membuat pembaca seolah-olah mengalami sendiri peristiwa yang diceritakan. Dengan demikian, pembaca akan turut merasakan perjuangan Kyai Hasan Mukmin dan mengenal sosok kepahlawanan beliau.

\section{SIMPULAN}

Nilai kepahlawanan yang ada dalam diri Kyai Hasan Mukmin adalah ulet, rela berkorban, berjiwa pemimpin, teladan, gigih, pantang mundur, dan berjiwa pelopor. Pemanfaatan nilai kepahlawanan Kyai Hasan Mukmin digunakan sebagai bahan ajar pendidikan karakter yang disajikan dalam cerita narasi berjudul "Kyai Hasan Mukmin, Pahlawan dari Sidoarjo".

\section{UCAPAN TERIMA KASIH}

Terima kasih peneliti ucapkan kepada Universitas PGRI Adi Buana yang telah memberikan sponsor dalam penelitian ini.

\section{REFERENSI}

A. Doni, K. (2007). Pendidikan Karakter: Strategi Mendidik di Zaman Global. Jakarta: Grasindo.

Aisyah, S., Noviyanti, E., \& Triyanto. (2020). Bahan Ajar sebagai bagian dalam Kajian Problematika Pembelajaran Bahasa Indonesia. Jurnal Salaka, 62-65.

Amrulloh, M. H., Haq, A., \& Madyan, S. (2020). Internalisasi Nilai - Nilai Keteladanan Tokoh Islam Raden Patah pada Pembelajaran PAI Siswa Kelas VIII: Studi Kasus di Mts. Al-Hamid Malang. Jurnal Vicratina: Jurnal Pendidikan Islam, 92-98.

Andina, V., Sugiharto, \& Imamudin. (2020). Nilai Kepahlawanan dalam Serat Kridhawasita: Kajian Filologi. Jurnal Alfabeta: Jurnal Bahasa, Sastra, dan Pembelajarannya, 56-62.

Arifin, M. Z., Katrini, Y. E., \& H. Theresia P. R. N. (2020). Nilai-Nilai Perjuangan Tokoh Utama dalam Novel Dunia Samin Karya Soesilo Toer: Tinjauan Sosiologi Sastra dan Implementasinya sebagai Materi Ajar Pembelajaran Sastra di SMA. Jurnal Repetisi: Riset Pendidikan Bahasa dan Sastra Indonesia, 2638.

Arsip. (2014). Nilai-Nilai Kepahlawanan, Arsip, dan Revolusi Mental. Retrieved Maret 31, 2020, from https://anri.go.id/publikasi/majalah-arsip

Badrun, U. (2006). Pahlawan. Jakarta: Perspektif. 
Bulan, A. \& Hasan. (2020). Analisis Nilai Pendidikan Karakter dalam Kumpulan Dongeng Suku Mbojo. Jurnal Ainara: Jurnal Penelitian dan PKM Bidang Ilmu Pendidikan, 31-38.

Efendi, A. (2020). Nilai Karakter dalam Novel Biografi Hatta: Aku Datang karena Sejarah Karya Sergius Sutanto. Jurnal Pendidikan Karakter, 14-32.

Farhat, P. N. F. A. \& Z, Anis F. (2020). Memperkenalkan Sejarah Pahlawan Nasional K.H Agus Salim bagi Peserta Didik MI/SD di Indonesia. Jurnal As Sibyan: Jurnal Kajian Kritis Pendidikan Islam dan Manajemen Pendidikan Dasar, 18-33.

Fransiska, M. \& Listyarini, I. (2017). Analisis Kemampuan Penggunaan Ejaan dalam Karangan Narasi Siswa Kelas V SDN Tlogosari Kulon 05 Semarang. Lingua, 68-76.

Gusar, M. R. S. \& Irene, L. (2019). Peningkatan Kemampuan Siswa Menulis Karangan Narasi Berbasis Acara Televisi "Jika Aku Menjadi" Trans Tv. Jurnal Dinamika Pendidikan, 205-211.

Hadiah, N. dan Z, Anis F. (2020). Memperkenalkan Sejarah Pahlawan Nasional Mr. Raden Achmad Soebardjo Djojoadisoejo bagi Peserta Didik MI/SD di Indonesia. Jurnal As Sibyan: Jurnal Kajian Kritis Pendidikan Islam dan Manajemen Pendidikan Dasar, 79-95.

Istiqamah. (2020). Nilai Moral dan Patriotisme dalam Film Disney Moana. Jurnal SeBaSa: Jurnal Pendidikan Bahasa dan Sastra Indonesia, 56-65.

Keraf, G. (1991). Argumentasi dan Narasi. Jakarta: Gramedia.

Khoirurrohman, T. \& Anjany A. (2020). Cerita Rakyat Kabupaten Purworejo sebagai Upaya Implementasi Pendidikan Karakter Berbasis Kearifan Lokal di Sekolah Dasar. Jurnal Pendidikan Dasar, 12-21.

Ningsi, N. P. S. (2017). Kemampuan Menulis Karangan Narasi Melalui Media Animasi Siswa Kelas VIII SMP Negeri 07 Palopo. Jurnal Onoma: Pendidikan Bahasa dan Sastra, 44-56.

Nugraha, M. T. (2019). Rekonsiliasi Nilai-Nilai Kepahlawanan serta Internalisasinya dalam Pendidikan Islam. Jurnal Pendidikan Islam Ta'dibuna, 241-258.

Nurjaya, G. (2012). Pengembangan Bahan Ajar Metode Pembelajaran Bahasa dan Sastra Indonesia berbasis Pembelajaran Kooperatif Jigsaw untuk Meningkatkan Pemahaman dan Kemampuan Aplikatif Mahasiswa. Jurnal Pendidikan Indonesia, 102-111.

Putro, A. P., Waluyo, J. H., \& Wardhani, N. E. (2020). Nilai-Nilai Pendidikan Karakter dalam Naskah Drama Opera Kecoa Karya N. Riantiarno. Jurnal Dialektika: Jurnal Bahasa, Sastra, dan Pendidikan Bahasa dan Sastra Indonesia, 1-16.

Rahmadani, S., Suhartono., \& Arifin, M. (2017). Kemampuan Menulis Teks Narasi Tentang Pengalaman Libur Sekolah Siswa Kelas VII SMP Negeri 1 Bermani Ilir Kabupaten Kepahiang. Jurnal Ilmiah Korpus, 218-223.

Samani, M., dan Hariyanto. (2011). Konsep dan Model Pendidikan Karakter. Bandung: Remaja Rosdakarya. 
Saraswati, E. \& Budiman, A. (2016). Karakter Kepemimpinan dalam Novel Silat Nagabumi Karya Seno Gumirah Ajidarma sebagai Bahan Ajar Sastra di Sekolah Menengah. Jurnal Kembara: Jurnal Keilmuan Bahasa, Sastra, dan Pengajarannya, 157-165.

Setiawan, A. \& Qur'ani, H. B. (2017). Nilai Karakter Cinta Lingkungan melalui Karaktersitik Tokoh pada Novel dari Rahim Ombak Karya Tison Sahabuddin Bungin. Jurnal Kembara: Jurnal Keilmuan Bahasa, Sastra, dan Pengajarannya, 149-160.

Windiatmoko, D. U. (2016). Analisis Wacana dalam Gurindam XII dan Nilai Pendidikan Karakter serta Implikasinya sebagai Materi Ajar Sastra. Jurnal Kembara: Jurnal Keilmuan Bahasa, Sastra, dan Pengajarannya, 12-22. 